\begin{tabular}{|c|c|}
\hline Title & Hydration study of slag-blended cement based on thermodynamic considerations \\
\hline Author(s) & Elakneswaran, Y ogarajah; Owaki, Eiji; Miyahara, Shigey oshi; Ogino, Masataka; Maruya, T suyoshi; Nawa, Toyoharu \\
\hline Citation & $\begin{array}{l}\text { Construction and building materials, 124, 615-625 } \\
\text { https://doi.org/10.1016/.conbuildmat.2016.07.138 }\end{array}$ \\
\hline Issue Date & 2016-10-15 \\
\hline Doc URL & http:/hdl.handle.net/2115/71657 \\
\hline Rights & $\begin{array}{l}\text { (c) 2016, Elsevier. Licensed under the Creative Commons A ttribution-NonCommercial- NoDerivatives 4.0 International } \\
\text { http://creativecommons.org/icenses/by-nc-nd/4.0/ }\end{array}$ \\
\hline Rights(URL) & http://creativecommons.org/icenses/by-nc-nd/4.0/ \\
\hline Type & article (author version) \\
\hline File Information & Slag-Hydration_Manuscript-Revised.pdf \\
\hline
\end{tabular}

Instructions for use 


\section{Hydration study of slag-blended cement based on thermodynamic}

2 considerations

3

4 Yogarajah Elakneswaran ${ }^{1 *}$, Eiji Owaki ${ }^{2}$, Shigeyoshi Miyahara ${ }^{2}$, Masataka Ogino ${ }^{2}$, Tsuyoshi

5 Maruya $^{2}$, Toyoharu Nawa ${ }^{1}$

6

$7 \quad{ }^{1}$ Division of Sustainable Resources Engineering

8 Faculty of Engineering

9 Hokkaido University

10 Kita 13, Nishi 8, Kita-ku, Sapporo,

11 060-8628, Japan

12

$13{ }^{2}$ Civil Structure and Material Research Section,

14 Civil Engineering Research Institute

15 Technology Centre, Taisei Corporation

16 344-1, Nase-cho, Totsuka-ku, Yokohama

17 245-0051, Japan

18

$19 *$ Corresponding author

20 E-mail: elakneswaran@eng.hokudai.ac.jp

21 Tel: +81-11-706-6918, Fax: +81-11-706-6918

22

23

Abstract

24 Thermodynamic calculations, using the geochemical code PHREEQC coupled with empirical

25 equations for kinetics of cement hydration and slag reaction, were carried out to predict the 26 compositions of the hydrate assemblage and pore solutions of hydrating Portland cement and 
0

cement blended with slag and the blended cement containing limestone. The predicted compositions of hydration products and element concentrations in pore solutions compared well with experimental data reported in literature. The calculation results showed the varying $\mathrm{Ca} / \mathrm{Si}$ and $\mathrm{Al} / \mathrm{Si}$ ratios of calcium aluminosilicate hydrate $(\mathrm{C}-\mathrm{A}-\mathrm{S}-\mathrm{H})^{*}$ in the hydration products due to hydration and slag addition. Limitations on the equation for reaction of slag and the importance of a C-A-S-H solid solution model in prediction of hydration products are discussed.

Keywords: Thermodynamic Calculations; Slag-blended Cement; Hydration Products; Pore Solution; PHREEQC

\section{INTRODUCTION}

A partial replacement of Portland cement (PC) by supplementary cementitious materials (SCMs) or innovative low-carbon cement-based materials can substantially reduce $\mathrm{CO}_{2}$ emissions associated with PC production [1]. Several studies have focused on developing SCMs from a variety of waste and by-product materials, in addition to common SCMs such as fly ash, ground granulated blast-furnace slag, and silica fume [2]. Further, novel cement systems/concrete are being developed through alkaline activation of aluminosilicates or innovative uses of waste materials [3]. Some of these novel cements are in use on a limited scale in some parts of the world; however, their shortand long-term performance as compared to conventional PC needs to be established for their large-scale application [1]. More investigation on the properties and performance of SCMs or novel cements is necessary for their successful usage as partial or complete replacement of PC in concrete.

Knowledge of hydrating cement and the cementitious behaviour and pozzolanic characteristics of

\footnotetext{
* Cement chemistry shorthand notations: $\mathrm{A}=\mathrm{Al}_{2} \mathrm{O}_{3}, \mathrm{C}=\mathrm{CaO}, \mathrm{S}=\mathrm{SiO}_{2}$, and $\mathrm{H}=\mathrm{H}_{2} \mathrm{O}$
} 
SCMs are important for better understanding of the properties and performance of the materials in concrete. It is also essential in terms of materials selection for concrete and for predicting properties and the durability and structural performance of concrete. The properties of hydrated PC and blended cement can be determined by laboratory experiments. However, it is difficult to depend entirely on experimental methods to determine the properties owing to the variety of SCMs used and the time it takes to perform these experiments. On the other hand, thermodynamic or mathematical models significantly reduce the reliance on laboratory experiments and help to predict hydration processes and materials properties.

Thermodynamic models in cementitious systems would make it possible to predict the composition of the hydrate assemblage and the aqueous phase composition based on information about the starting materials. Rothstein [4] studied the saturation indexes of solid phases in hydrating PC during the first 28 days of hydration using thermodynamic analysis of the element concentrations and compared the calculated saturation indexes with the supersaturation of phases found in previous work. Lothenbach and associates [5-12] made significant contributions to the thermodynamic calculations for cementitious materials to better understand cement hydration processes. Their work facilitated prediction of the composition of solid and liquid phases during hydration as a function of hydration time and simulation of the phase changes in cementitious materials in contact with ionic solutions. A thermodynamic model developed using the Gibbs free energy minimisation program GEMS-PSI (available at http://gems.web.psi.ch/) coupled with kinetic equations for the dissolution of clinker minerals successfully predicted the solid-phase assemblage and pore solution composition of hydrated PC [7] and PC-containing limestone [7 and 9]. The model was extended to allow calculations in the temperature range of $0-100{ }^{\circ} \mathrm{C}[10]$; it was also applied to various cements [8] and mineral admixtures [5 and 12]. In addition to thermodynamic models, several hydration models in cementitious materials have been proposed to simulate the hydration reaction of cement and slag and also to predict the evolution of hydration products [13-14]. It is recognised that a 
partial or complete replacement of PC with slag reduces the $\mathrm{Ca} / \mathrm{Si}$ ratio of calcium silicate hydrate (C-S-H) and also forms calcium aluminosilicate hydrate (C-A-S-H) [2, and 15-16]. The incorporation of aluminium in C-S-H of PC has also been reported in previous studies [2 and16]. However, details of these aspects have not yet been taken into account in existing models for predicting the composition of the hydrate assemblage and pore solution chemistry. A model that includes $\mathrm{Al}$ incorporation and various $\mathrm{Ca} / \mathrm{Si}$ ratios of $\mathrm{C}-\mathrm{S}-\mathrm{H}$ is thus important for better prediction of the solid products and aqueous phase compositions formed in PC and slag-blended systems.

In this study, chemical thermodynamic calculations were carried out to predict the solid-phase assemblages and pore solution composition of hydrating PC and slag as a function of hydration time. An integrated model that coupled PHREEQC [17-18] with empirical expressions for dissolution of clinker minerals and reactions of slag was developed, in which, the reactions among solids, aqueous solutions, and solid solutions were considered simultaneously at each hydration time step. Various calculation features built into PHREEQC including phase-equilibrium, speciation, and solid solutions, allowed the performance of a variety of geochemical calculations at higher ionic strengths as well, using an incorporated Pitzer model [19]. A solid solution that consists of various C-S-H and C-A-S-H gels as end-members was considered to account for the changing $\mathrm{Ca} / \mathrm{Si}$ ratio and aluminium uptake in the gels [15 and 20]. The results of thermodynamic calculations in terms of solid-phase composition and concentration of elements in the pore solution were compared with the experimental data in literature for hydrating PC, cement blended with slag, and blended cement containing limestone.

\section{MODEL DESCRIPTION}

\subsection{Thermodynamic model}

In this study, a phase-equilibrium module in PHREEQC was employed to carry out thermodynamic 
104

105

106

107

108

109

110

111

112

113

114

$K_{p}=\exp \left(-\frac{\Delta_{r} G_{T}^{0}}{R T}\right)$

115

$$
K_{p}=\prod_{i}\left(\gamma_{i} c_{i}\right)^{n_{i, p}}
$$
as

equilibrium calculations [17-18]. When a pure phase is no longer in equilibrium with a solution, it will dissolve or precipitate. The equilibrium reactions are expressed by the mass-action equation as

where $K_{p}$ is the thermodynamic equilibrium constant for phase $p, \gamma_{i}$ is the activity coefficient of ion $i$ $(-), c_{i}$ is the concentration of ion $i(\mathrm{~mol} / \mathrm{L})$, and $n_{i, p}$ is the stoichiometric coefficient of ion $i$ in phase $p(-)$. The thermodynamic equilibrium constant, $K_{p}$, at a given temperature $T(\mathrm{~K})$ can be expressed

where $\Delta_{r} G_{T}^{0}$ is the standard Gibbs energy of reaction at temperature $T$ and $R$ is the universal gas constant $(8.31451 \mathrm{~J} /(\mathrm{mol} \mathrm{K}))$. The standard Gibbs energy of reaction is expressed as

$$
\Delta_{r} G_{T}^{0}=\sum \Delta_{f} G_{T, \text { products }}^{0}-\sum \Delta_{f} G_{T, \text { reactants }}^{0}
$$

where $\Delta_{f} G_{T}{ }^{0}$ is the Gibbs free energy of formation for a species at a given temperature $T$. The equilibrium constant $\left(\log K_{p}\right)$ and the standard heats of reaction $\left(\Delta_{r} H^{0}\right)$, which is used in the Van't Hoff equation (Appelo and Postma 2009) to determine temperature dependence of the equilibrium constant, for the dissolution reactions of phases used in the simulation are tabulated in Table 1. The name of the phase (defined by dissolution reaction, $\log K_{p}$, and $\Delta_{r} H^{0}$, as given in Table 1), the specified saturation index (which has a value of zero for equilibrium), and the amount of the phase were the input parameters for the phase-equilibrium module in PHREEQC. 
129 Table 1 Thermodynamic properties of the phases at $25^{\circ} \mathrm{C}$ used in the calculations [10, 15, and 18]

\begin{tabular}{|c|c|c|c|c|}
\hline Phase & Reactions & $\log K_{p}$ & $\triangle_{r} H^{0}$ & Ref. \\
\hline Anhydrite & $\mathrm{CaSO}_{4} \leftrightarrow \mathrm{Ca}^{2+}+\mathrm{SO}_{4}^{2-}$ & -4.36 & -1.71 & {$[18]$} \\
\hline Brucite & $\mathrm{Mg}(\mathrm{OH})_{2}+2 \mathrm{H}^{+} \leftrightarrow \mathrm{Mg}^{2+}+2 \mathrm{H}_{2} \mathrm{O}$ & 17.07 & -115.66 & {$[10]$} \\
\hline $\mathrm{C}_{3} \mathrm{AH}_{6}$ & $\begin{array}{l}\mathrm{Ca}_{3} \mathrm{Al}_{2}(\mathrm{OH})_{12}+12 \mathrm{H}^{+} \leftrightarrow 3 \mathrm{Ca}^{2+}+2 \mathrm{Al}^{3+}+ \\
12 \mathrm{H}_{2} \mathrm{O}\end{array}$ & 82.22 & -595.76 & [10] \\
\hline $\mathrm{C}_{3} \mathrm{FH}_{6}$ & $\begin{array}{l}\mathrm{Ca}_{3} \mathrm{Fe}_{2}(\mathrm{OH})_{12}+12 \mathrm{H}^{+} \leftrightarrow 3 \mathrm{Ca}^{2+}+2 \mathrm{Fe}^{3+}+ \\
12 \mathrm{H}_{2} \mathrm{O}\end{array}$ & 73.65 & -516.96 & [10] \\
\hline Calcite & $\begin{array}{l}\mathrm{CaCO}_{3} \leftrightarrow \mathrm{Ca}^{2+}+\mathrm{CO}_{3}^{2-} \\
(\mathrm{CaO})_{1.25}\left(\mathrm{Al}_{2} \mathrm{O}_{3}\right)_{0.125}\left(\mathrm{SiO}_{2}\right): 1.625 \mathrm{H}_{2} \mathrm{O}\end{array}$ & -8.48 & -2.297 & [18] \\
\hline CASH_5CA & $\begin{array}{l}3.25 \mathrm{H}^{+} \leftrightarrow 1.25 \mathrm{Ca}^{2+}+0.25 \mathrm{Al}^{3+}+\mathrm{H}_{4} \mathrm{SiO}_{4}+ \\
1.25 \mathrm{H}_{2} \mathrm{O}\end{array}$ & 22.00 & -141.58 & [15] \\
\hline CASH_INFCA & $\begin{array}{l}(\mathrm{CaO})\left(\mathrm{Al}_{2} \mathrm{O}_{3}\right)_{0.15625}\left(\mathrm{SiO}_{2}\right)_{1.1875}: 1.65625 \mathrm{H}_{2} \mathrm{O}+ \\
2.9375 \mathrm{H}^{+} \leftrightarrow \mathrm{Ca}^{2+}+0.3125 \mathrm{Al}^{3+}+ \\
1.1875 \mathrm{H}_{4} \mathrm{SiO}_{4}+0.75 \mathrm{H}_{2} \mathrm{O}\end{array}$ & 16.60 & -110.67 & [15] \\
\hline CSH_T2C & $\begin{array}{l}(\mathrm{CaO})_{1.5}\left(\mathrm{SiO}_{2}\right): 2.5 \mathrm{H}_{2} \mathrm{O}+3 \mathrm{H}^{+} \leftrightarrow 1.5 \mathrm{Ca}^{2+}+ \\
\mathrm{H}_{4} \mathrm{SiO}_{4}+2 \mathrm{H}_{2} \mathrm{O}\end{array}$ & 25.88 & -127.10 & [15] \\
\hline CSH_T5C & $\begin{array}{l}(\mathrm{CaO})_{1.25}\left(\mathrm{SiO}_{2}\right)_{1.25}: 2.5 \mathrm{H}_{2} \mathrm{O}+2.5 \mathrm{H}^{+} \leftrightarrow \\
1.25 \mathrm{Ca}^{2+}+1.25 \mathrm{H}_{4} \mathrm{SiO}_{4}+1.25 \mathrm{H}_{2} \mathrm{O}\end{array}$ & 18.74 & -83.46 & [15] \\
\hline CSH_Jen & $\begin{array}{l}(\mathrm{CaO})_{1.667}\left(\mathrm{SiO}_{2}\right): 2.1 \mathrm{H}_{2} \mathrm{O}+3.334 \mathrm{H}^{+} \leftrightarrow \\
1.667 \mathrm{Ca}^{2+}+\mathrm{H}_{4} \mathrm{SiO}_{4}+1.767 \mathrm{H}_{2} \mathrm{O}\end{array}$ & 29.60 & -148.44 & [10] \\
\hline CSH_TobH & $\begin{array}{l}(\mathrm{CaO})\left(\mathrm{SiO}_{2}\right)_{1.5}: 2.5 \mathrm{H}_{2} \mathrm{O}+2 \mathrm{H}^{+} \leftrightarrow \mathrm{Ca}^{2+}+ \\
1.5 \mathrm{H}_{4} \mathrm{SiO}_{4}+0.5 \mathrm{H}_{2} \mathrm{O}\end{array}$ & 13.18 & -47.83 & [15] \\
\hline Ettringite & $\begin{array}{l}\mathrm{Ca}_{6} \mathrm{Al}_{2}\left(\mathrm{SO}_{4}\right)_{3}(\mathrm{OH})_{12}: 26 \mathrm{H}_{2} \mathrm{O}+12 \mathrm{H}^{+} \leftrightarrow 6 \mathrm{Ca}^{2+} \\
+2 \mathrm{Al}^{3+}+3 \mathrm{SO}_{4}{ }^{2-}+38 \mathrm{H}_{2} \mathrm{O}\end{array}$ & 57.73 & -389.36 & [10] \\
\hline Gypsum & $\mathrm{CaSO}_{4}: 2 \mathrm{H}_{2} \mathrm{O} \leftrightarrow \mathrm{Ca}^{2+}+\mathrm{SO}_{4}^{2-}+2 \mathrm{H}_{2} \mathrm{O}$ & -4.58 & -0.109 & [18] \\
\hline Hemicarboaluminate & $\begin{array}{l}\mathrm{Ca}_{4} \mathrm{Al}_{2}\left(\mathrm{CO}_{3}\right)_{0.5}(\mathrm{OH})_{13}: 5.5 \mathrm{H}_{2} \mathrm{O}+13 \mathrm{H}^{+} \leftrightarrow \\
4 \mathrm{Ca}^{2+}+2 \mathrm{Al}^{3+}+0.5 \mathrm{CO}_{3}^{2-}+18.5 \mathrm{H}_{2} \mathrm{O}\end{array}$ & 87.88 & -604.27 & [10] \\
\hline Hydrotalcite & $\begin{array}{l}\mathrm{Mg}_{4} \mathrm{Al}_{2}(\mathrm{OH})_{14}: 3 \mathrm{H}_{2} \mathrm{O}+14 \mathrm{H}^{+} \leftrightarrow 2 \mathrm{Al}^{3+}+ \\
4 \mathrm{Mg}^{2+}+17 \mathrm{H}_{2} \mathrm{O}\end{array}$ & 75.97 & -607.91 & [10] \\
\hline Monocarboaluminate & $\begin{array}{l}\mathrm{Ca}_{4} \mathrm{Al}_{2}\left(\mathrm{CO}_{3}\right)(\mathrm{OH})_{12}: 5 \mathrm{H}_{2} \mathrm{O}+12 \mathrm{H}^{+} \leftrightarrow 4 \mathrm{Ca}^{2+}+ \\
2 \mathrm{Al}^{3+}+\mathrm{CO}_{3}{ }^{2-}+17 \mathrm{H}_{2} \mathrm{O}\end{array}$ & 71.54 & -533.14 & [10] \\
\hline Monosulfoaluminate & $\begin{array}{l}\mathrm{Ca}_{4} \mathrm{Al}_{2}\left(\mathrm{SO}_{4}\right)(\mathrm{OH})_{12}: 6 \mathrm{H}_{2} \mathrm{O}+12 \mathrm{H}^{+} \leftrightarrow 4 \mathrm{Ca}^{2+}+ \\
2 \mathrm{Al}^{3+}+\mathrm{SO}_{4}{ }^{2-}+18 \mathrm{H}_{2} \mathrm{O}\end{array}$ & 73.68 & -553.08 & [10] \\
\hline Portlandite & $\mathrm{Ca}(\mathrm{OH})_{2}+2 \mathrm{H}^{+} \leftrightarrow \mathrm{Ca}^{2+}+2 \mathrm{H}_{2} \mathrm{O}$ & 22.79 & -129.66 & {$[10]$} \\
\hline Stratlingite & $\begin{array}{l}\mathrm{Ca}_{2} \mathrm{Al}_{2} \mathrm{SiO}_{2}(\mathrm{OH})_{10}: 3 \mathrm{H}_{2} \mathrm{O}+10 \mathrm{H}^{+} \leftrightarrow 2 \mathrm{Ca}^{2+}+ \\
2 \mathrm{Al}^{3+}+\mathrm{H}_{4} \mathrm{SiO}_{4}+11 \mathrm{H}_{2} \mathrm{O}\end{array}$ & 51.42 & -408.12 & [10] \\
\hline
\end{tabular}


133 In this study, the cement hydration model proposed by Parrot and Killoh [21] was used to estimate 134 the hydration degree of each cement clinker mineral as a function of time. The model is described in 135 detail elsewhere [7, 9, and 21]; the main equations are briefly described here. Parrot and Killoh [21] 136 derived a set of empirical equations to describe the hydration rate, $R_{t}^{m}$, of an individual clinker 137 mineral $m$ at time $t\left(m=C_{3} S, C_{2} S, C_{3} A, C_{4} A F\right)$ :

138

139 Nucleation and growth

140

$141 \quad R_{t, 1}^{m}=\frac{K_{1}}{N_{1}}\left[1-\alpha_{t}^{m}\right]\left\{-\ln \left(1-\alpha_{t}^{m}\right)\right\}^{\left(1-N_{1}\right)}$

$$
R_{t, 2}^{m}=\frac{K_{2}\left(1-\alpha_{t}^{m}\right)^{2 / 3}}{1-\left(1-\alpha_{t}^{m}\right)^{1 / 3}}
$$

$$
R_{t, 3}^{m}=K_{3}\left(1-\alpha_{t}^{m}\right)^{N_{3}}
$$

151 The associated empirical parameters in the equations are tabulated in Table 2 as reported by 152 Lothenbach et al. [9-10]. The minimum among above the rates $\left(R_{t, 1}^{m}, R_{t, 2}^{m}, R_{t, 3}^{m}\right)$ is considered to be 153 the controlling rate. The hydration degree of clinker mineral $m$ at the time $t, \alpha_{t}^{m}$, is calculated from 154 the hydration degree of the mineral at the previous time step $\left(\alpha_{t-1}{ }^{m}\right)$, the time interval $\left(\Delta_{t}\right)$, and 155 hydration rate of the clinker mineral at the previous time step $\left(R_{t-1}{ }^{m}\right)$ as 
$\alpha_{t}^{m}=\alpha_{t-1}^{m}+\Delta t \cdot \min \left(R_{t-1,1}^{m}, R_{t-1,2}^{m}, R_{t-1,3}^{m}\right) \cdot \beta_{w / c} \cdot \lambda_{R H} \cdot \frac{A}{A_{0}} \cdot \exp \left[\frac{E_{a}^{m}}{R}\left(\frac{1}{T_{0}}-\frac{1}{T}\right)\right]$

158 where,

159

$\beta_{w / c}=\left[1+3.333 \times\left(H^{m} \times w / c-\alpha_{t-1}\right)\right]^{4} \quad$ if $\quad \alpha_{t}>H^{m} \times w / c$

$160 \quad \beta_{w / c}=1$

if $\quad \alpha_{t} \leq H^{m} \times w / c$

$161 \quad \lambda_{R H}=\left(\frac{R H-0.55}{0.45}\right)^{4}$

163 where $H^{m}$ is the critical degree of the clinker mineral $m, w / c$ is the water to cement ratio, $\alpha_{t-1}$ is the 164 total hydration degree of cement at the previous time step, $A$ is the Blaine surface area of cement $165\left(\mathrm{~m}^{2} / \mathrm{kg}\right), A^{0}$ is the reference surface area of cement $\left(385 \mathrm{~m}^{2} / \mathrm{kg}\right), E_{a}{ }^{m}$ is the apparent activation 166 energy of clinker mineral $m(\mathrm{~J} / \mathrm{mol}), T_{0}$ is the reference temperature $(293.15 \mathrm{~K})$, and $R H$ is the 167 relative humidity. The adapted values for $H^{m}$ and $E_{a}{ }^{m}$ are based on the work by Lothenbach et al. 168 [9-10], given in Table 2.

169

170 The total hydration degree of cement, $\alpha_{t}$, relative to the total clinker content at time $t$ is expressed by 171

$\alpha_{t}=\frac{f^{C_{3} S} \alpha_{t}^{C_{3} S}+f^{C_{2} S} \alpha_{t}^{C_{2} S}+f^{C_{3} A} \alpha_{t}^{C_{3} A}+f^{C_{4} A F} \alpha_{t}^{C_{4} A F}}{f^{C_{3} S}+f^{C_{2} S}+f^{C_{3} A}+f^{C_{4} A F}}$

where $f^{m}$ is the relative mass fraction of the cement clicker mineral $m$.

175

Table 2 Parameters adapted to calculate the hydration degree of the clinker minerals as a function

177 of time [9-10]

\begin{tabular}{lllll}
\hline & $\mathrm{C}_{3} \mathrm{~S}$ & $\mathrm{C}_{2} \mathrm{~S}$ & $\mathrm{C}_{3} \mathrm{~A}$ & $\mathrm{C}_{4} \mathrm{AF}$ \\
\hline $\mathrm{K}_{1}$ & 1.5 & 0.5 & 1 & 0.37
\end{tabular}




\begin{tabular}{llllll} 
& $\mathrm{N}_{1}$ & 0.7 & 1 & 0.85 & 0.7 \\
& $\mathrm{~K}_{2}$ & 0.05 & 0.006 & 0.04 & 0.015 \\
$\mathrm{~K}_{3}$ & 1.1 & 0.2 & 1 & 0.4 \\
& $\mathrm{~N}_{3}$ & 3.3 & 5 & 3.2 & 3.7 \\
& $\mathrm{H}$ & 1.8 & 1.35 & 1.60 & 1.45 \\
178 & $\mathrm{E}_{\mathrm{a}(\mathrm{J} / \mathrm{mol})}$ & 41570 & 20785 & 54040 & 34087 \\
\cline { 2 - 5 }
\end{tabular}

\section{SIMULATION RESULTS AND VERIFICATIONS}

\subsection{Ordinary Portland cement system}

\subsubsection{Modelling approach}

PHREEQC was coupled (using the IPhreeqc module [22]) with Excel ${ }^{\circledR}$ to carry out thermodynamic calculations in each time step. PHREEQC performs speciation and batch-reaction calculations to calculate the solution composition and the kind and amount of precipitated phases based on a thermodynamic dataset and input parameters. The calculations on the dissolution rate of clinker minerals were carried out in Excel ${ }^{\circledR}$ and the necessary data were transferred to PHREEQC as input parameters. The thermodynamic properties for various phases and minerals found in cement system were collected from CEMDATA07 [10] and others [15], and the data were converted into a format suitable for PHREEQC; the data are given in Table 1. The converted data, together with the PHREEQC default thermodynamic database [18], were used in in this study for every calculation. The following assumptions were considered to determine the compositions of the solid phases and pore solutions using the coupled model:

$\diamond \quad$ Free lime and alkali sulphates are dissolved completely as the cement comes into contact with water. $\mathrm{Ca}, \mathrm{O}$ as $\mathrm{OH}, \mathrm{Na}, \mathrm{K}$, and $\mathrm{S}$ are released into the pore solution.

$198 \diamond \mathrm{Na}_{2} \mathrm{O}$ and $\mathrm{K}_{2} \mathrm{O}$, which are present as minor components in the clinker minerals, and total MgO are dissolved by the total hydration degree of the cement and release $\mathrm{Na}, \mathrm{K}, \mathrm{Mg}$, and $\mathrm{O}$ as $\mathrm{OH}$ 
into the pore solution.

$201 \diamond$ Gypsum and calcite react continuously to reach equilibrium with the pore solution.

$202 \diamond$ The elements released into the pore solution form minerals and phases through thermodynamic 203 equilibrium.

$204 \diamond$ An ideal solid solution of six end-members (CASH_5CA, CASH_INFCA, CSH_T2C, 205 CSH_T5C, CSH_Jen, and CSH_TobH, as given in Table 1) is assumed for C-S-H and 206 C-A-S-H.

208 The alkalis are released from readily soluble alkalis sulphates and the dissolution of the clinker 209 minerals. It is well known that a part of the released alkalis are taken up by C-A-S-H gel, and a 210 distribution ratio $\left(R d_{N a}\right)$ of $0.45 \mathrm{~mL} / \mathrm{g}$ is used for $\mathrm{Na}^{+}$uptake by C-A-S-H gel while the distribution 211 ratio of $\mathrm{K}^{+}\left(R d_{K}\right)$ is expressed as follows [23]:

where $C_{K}$ is the concentration of $\mathrm{K}^{+}$.

\subsubsection{Simulation results and experimental data verification}

219 The predicted phase changes as a function of time for Ordinary Portland Cement (OPC) paste 220 (using the input parameters given in Table 3) are shown in Fig. 1(A). The model predicts the 221 complete dissolution of the available gypsum in the cement within the first $7 \mathrm{~h}$ of hydration and the 222 gradual increase in the amount of C-A-S-H end-members and portlandite with time. The presence 223 of CSH_TobH and CASH_INFCA end-members in C-A-S-H solid solution is negligible. 224 Magnesium present in the cement is predicted as brucite at an early age and then converted to hydrotalcite after 0.5 days of hydration. The model also calculates the continuous dissolution of 
226 calcite present in the cement to form monocarboaluminate, and some monocarboaluminate 227 transforms to hemicarboaluminate. The predicted phases in the hydrated OPC (after 7 days or 228 longer of hydration time) include C-A-S-H gel solid solution, portlandite, ettringite, hydrotalcite, 229 and AFm phases such as monocarboaluminate and hemicarboaluminate, in addition to un-hydrated 230 clinker minerals. The chemical composition data for end-members of the C-A-S-H gel solid 231 solution are used to predict the $\mathrm{Ca} / \mathrm{Si}$ and $\mathrm{Al} / \mathrm{Si}$ ratios of the gel (Fig. 1(B)). The predicted ratios of 232 hydrating $\mathrm{OPC}$ are $1.48 \leq \mathrm{Ca} / \mathrm{Si} \leq 1.53$ and $0.003 \leq \mathrm{Al} / \mathrm{Si} \leq 0.049$.

233

234 Table 3 Chemical composition and Blaine surface area of OPC and mixing conditions as input to 235 the model, adapted from ref. [9]

\begin{tabular}{|c|c|c|c|}
\hline \multicolumn{2}{|c|}{ Phase composition $(\mathrm{g} / 100 \mathrm{~g})$} & \multicolumn{2}{|c|}{ Minor components in the clinker phases } \\
\hline -Alite & 66.5 & $-\mathrm{Na}_{2} \mathrm{O}$ & 0.33 \\
\hline -Belite & 10.3 & $-\mathrm{K}_{2} \mathrm{O}$ & 0.06 \\
\hline -Aluminate & 7.5 & $-\mathrm{MgO}$ & $1.8^{*}$ \\
\hline -Ferrite & 8.5 & Mixing conditions & \\
\hline -CaO_Free & 0.93 & $-w / c$ & 0.4 \\
\hline -Calcite & 0.6 & -Temp ( $\left.{ }^{\circ} \mathrm{C}\right)$ & 20 \\
\hline -Gypsum & 3.1 & -RH (\%) & 1.0 \\
\hline$-\mathrm{Na}_{2} \mathrm{SO}_{4}$ & 0.21 & & \\
\hline$-\mathrm{K}_{2} \mathrm{SO}_{4}$ & 1.33 & Blaine surface area $\left(\mathrm{m}^{2} / \mathrm{kg}\right)$ & 413 \\
\hline
\end{tabular}



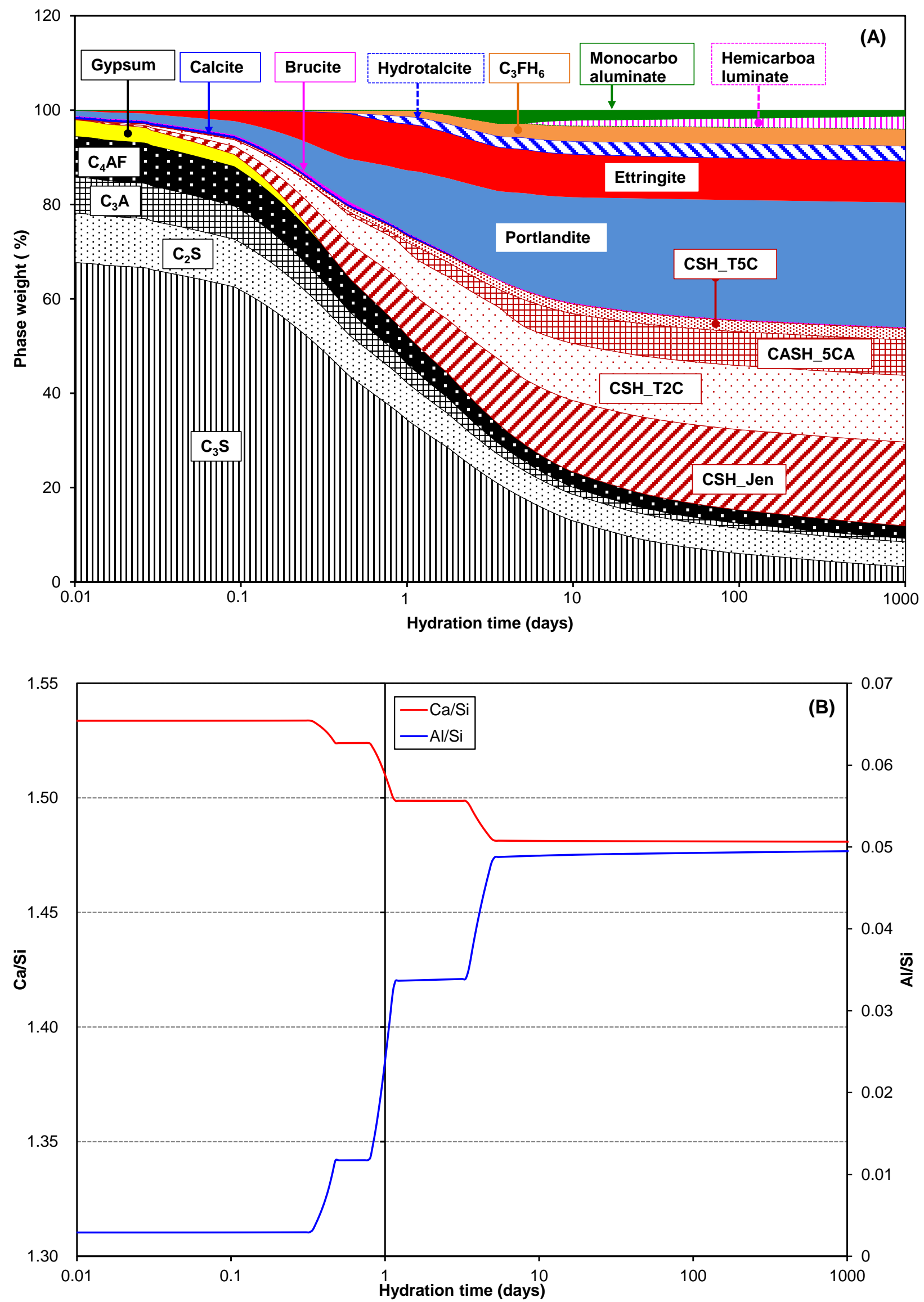

240 Fig. 1. Simulated phase (A), $\mathrm{Ca} / \mathrm{Si}$ and $\mathrm{Al} / \mathrm{Si}$ ratios of $\mathrm{C}-\mathrm{A}-\mathrm{S}-\mathrm{H}$ (B) changes as a function of 241 hydration time for OPC 
243 The simulated hydration products of OPC paste for the input parameters listed in Table 3 were 244 compared with the experimental data available in the literature [9], shown in Fig. 2. As reported by 245 Matschei [24] and validated by Lothenbach et al. [9], the AFm phases determined by XRD (X-ray 246 Diffraction) are certainly underestimated owing to their poor crystalline structure, relatively low 247 amount, and lack of data concerning the structure. Therefore, the total amorphous content (C-S-H + 248 amorphous AFm) from XRD measurement was compared with the summation of C-S-H and 249 monosulfoaluminate from the current simulation. As illustrated in Fig. 2, the predicted hydration 250 products of OPC are consistent with both the qualitative and quantitative experimental results as a 251 function of hydration time.

253 The ionic concentration in the pore solution was calculated based on the release and uptake of 254 alkalis as well as the thermodynamic equilibrium between the phases and the pore solution. The 255 comparison of computed elements concentration in the pore solution of hydrating OPC (for the 256 input parameters of Table 3) with experimentally determined ones [9] are shown in Fig. 3. The 257 model predicts reasonably well the changes of major elements such as $\mathrm{Na}, \mathrm{K}, \mathrm{OH}, \mathrm{Ca}, \mathrm{S}, \mathrm{Al}$, and $\mathrm{Si}$ 258 with hydration time, but the model cannot predict the presence of other elements such as Li, Sr, Ba, 259 Cr, and Mo, even though they can be detected in the experiments. The simulated concentration of 260 ions in pore solution is compared with another experimental data [25] to give further validation to 261 the proposed model. The simulated concentration of $\mathrm{Na}$, K, and Ca elements and $\mathrm{pH}$ of pore 262 solution are compared with experimental values of hydrating OPC with varying w/c ratios in Fig. 4. 263 It can be seen that the concentration of ions are predicted well though some discrepancies are 264 observed for $\mathrm{pH}$ at 1 and 3 days. 


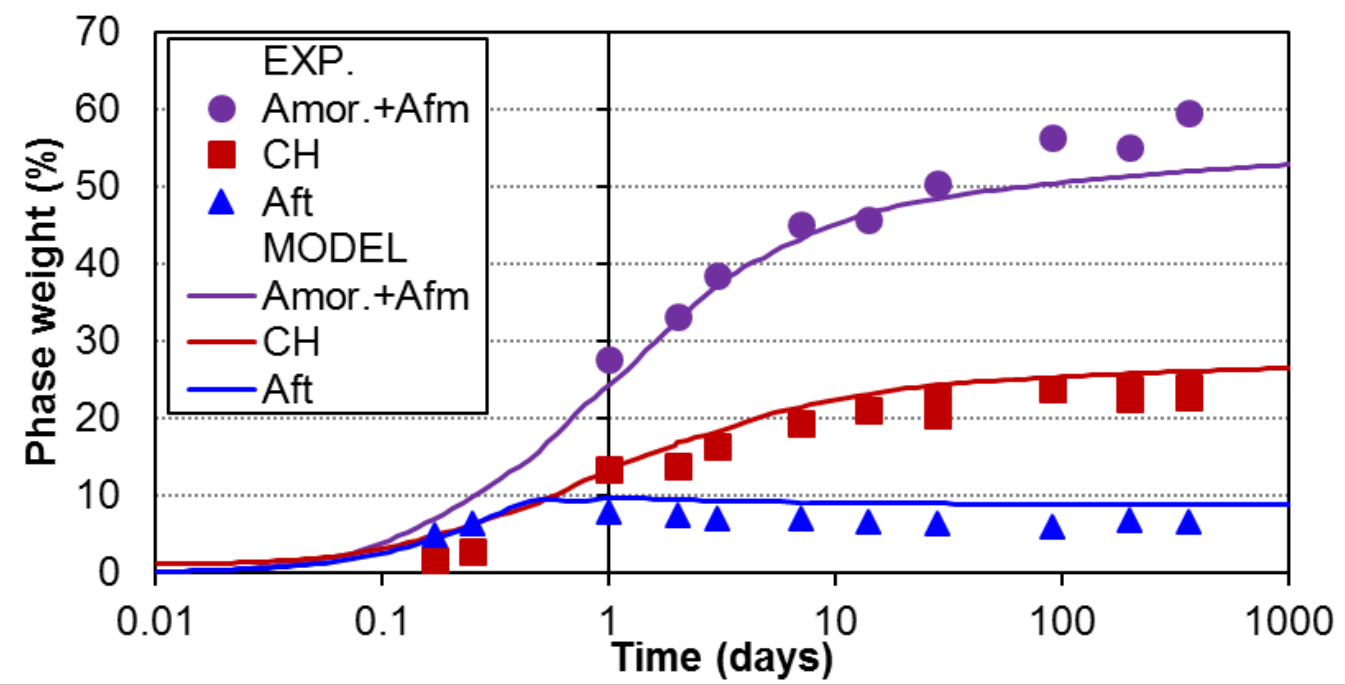

266 Fig. 2. Comparison of simulated portlandite, ettringite, and amorphous + Afm changes with experimental data [9] for hydrating OPC
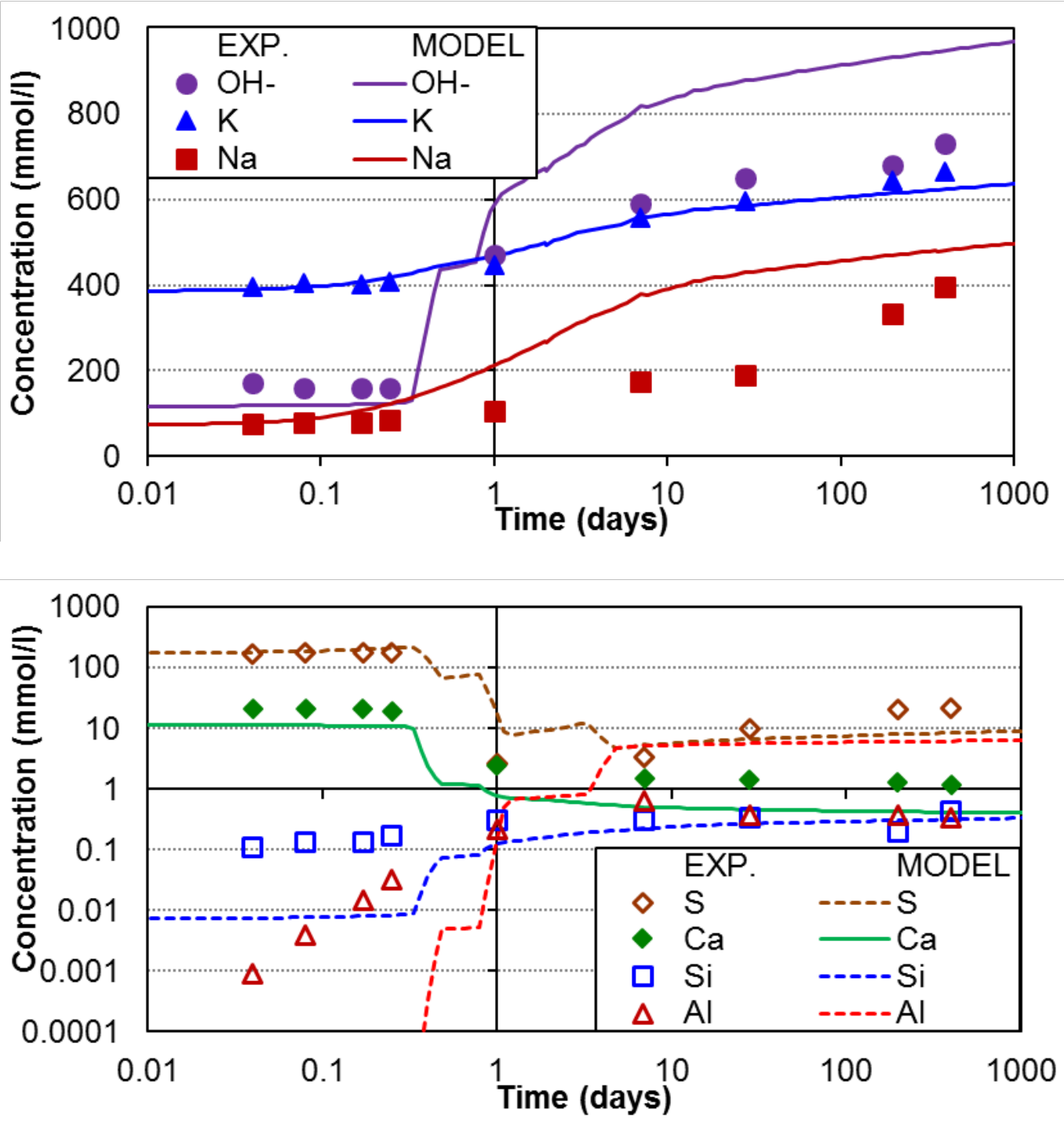

270 Fig. 3. Comparison of simulated pore solution concentration changes with experimental data [9] for 271 hydrating OPC 

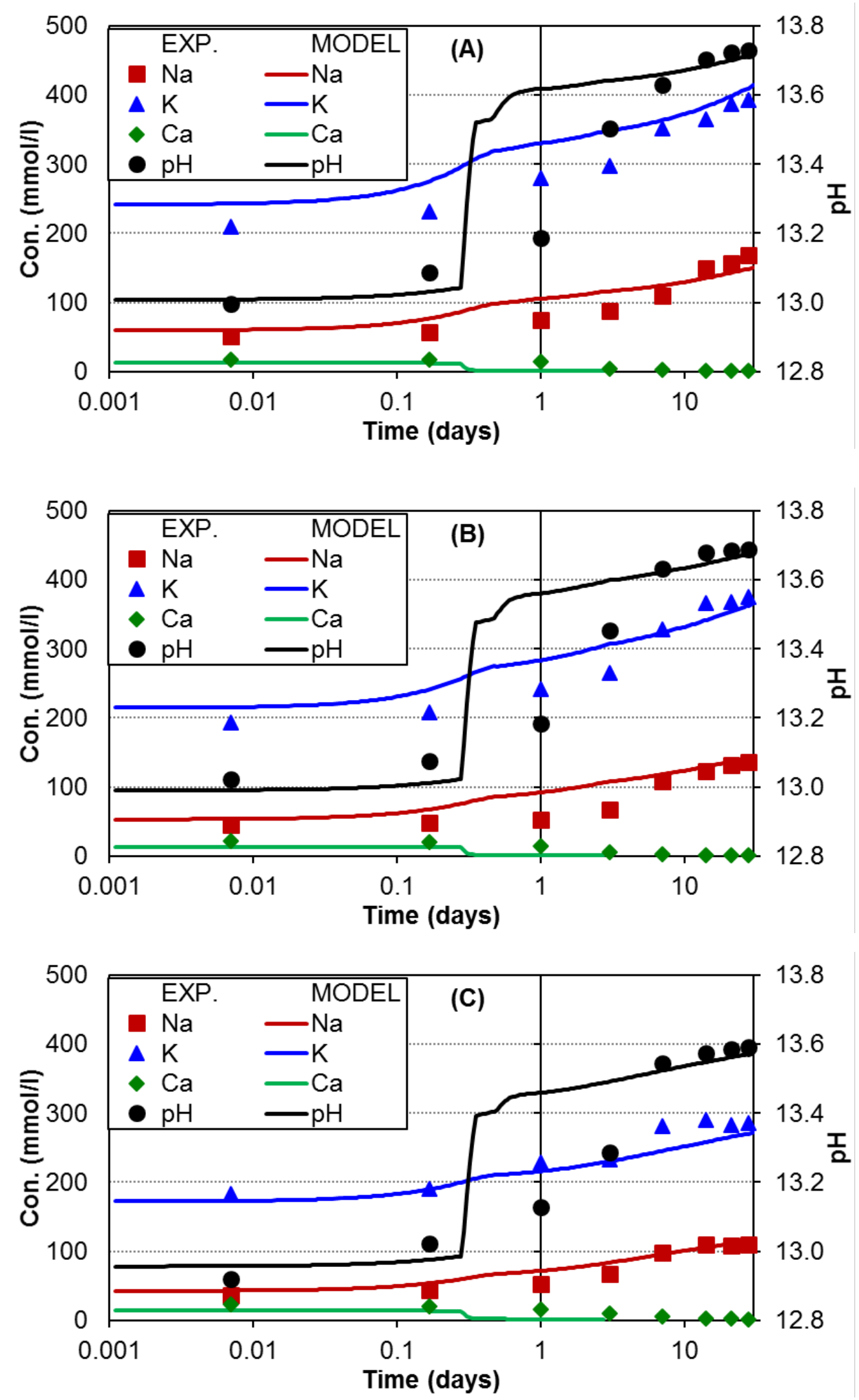

276 Fig. 4 Comparison of simulated pore solution concentration changes with experimental data [25] for

277 hydrating OPC with w/c of (A) 0.4 , (B) 0.45 , and (C) 0.56 


\subsection{Slag cement system}

\subsubsection{Modelling approach}

282 The coupled thermodynamic model described in section 3.1.1, including the solid solution model for C-S-H and C-A-S-H considered for the OPC system, with the same database and information relevant to cement hydration was also used to model the slag cement system. Thermodynamic 285 calculations were performed for the dissolution of clinker minerals and the reaction of slag at every time step. The ions released as result of cement clinker dissolution and the reaction of the glass phase of slag determined the kind and amount of the formed phases and the composition of experimental data (Fig. 5) available in the literature [26-30], which included the reaction degree for the cement replacement by slag of $20-60 \%$ for up to 2 years of hydration, to a function. The influence of temperature, using the Arrhenius equation, and the surface area of the slag were be described as follows:

$\alpha_{s g}=[A \times \ln (t)+B] \times S_{s g} \times \exp \left[-\frac{E_{S g}}{R}\left(\frac{1}{T}-\frac{1}{T_{0}}\right)\right]$

where,

$$
A=-0.16 \times r_{s g}+12.81
$$

$$
B=0.33 \times r_{s g}+4.30
$$

where $r_{s g}$ is the replacement ratio of slag (\%), $S A_{s g}$ is the Blaine value of slag $\left(\mathrm{cm}^{2} / \mathrm{g}\right)$, and $E_{s g}$ is the 
activation energy of slag ( $\mathrm{J} / \mathrm{mol})$, which was calculated from an equation given in ref. [31].

305 A distribution ratio of $0.45 \mathrm{~mL} / \mathrm{g}$ is used for both $\mathrm{Na}^{+}$and $\mathrm{K}^{+}$uptake by C-A-S-H gel in the cement 306 blended with slag system in order to predict ionic concentration in the pore solution.

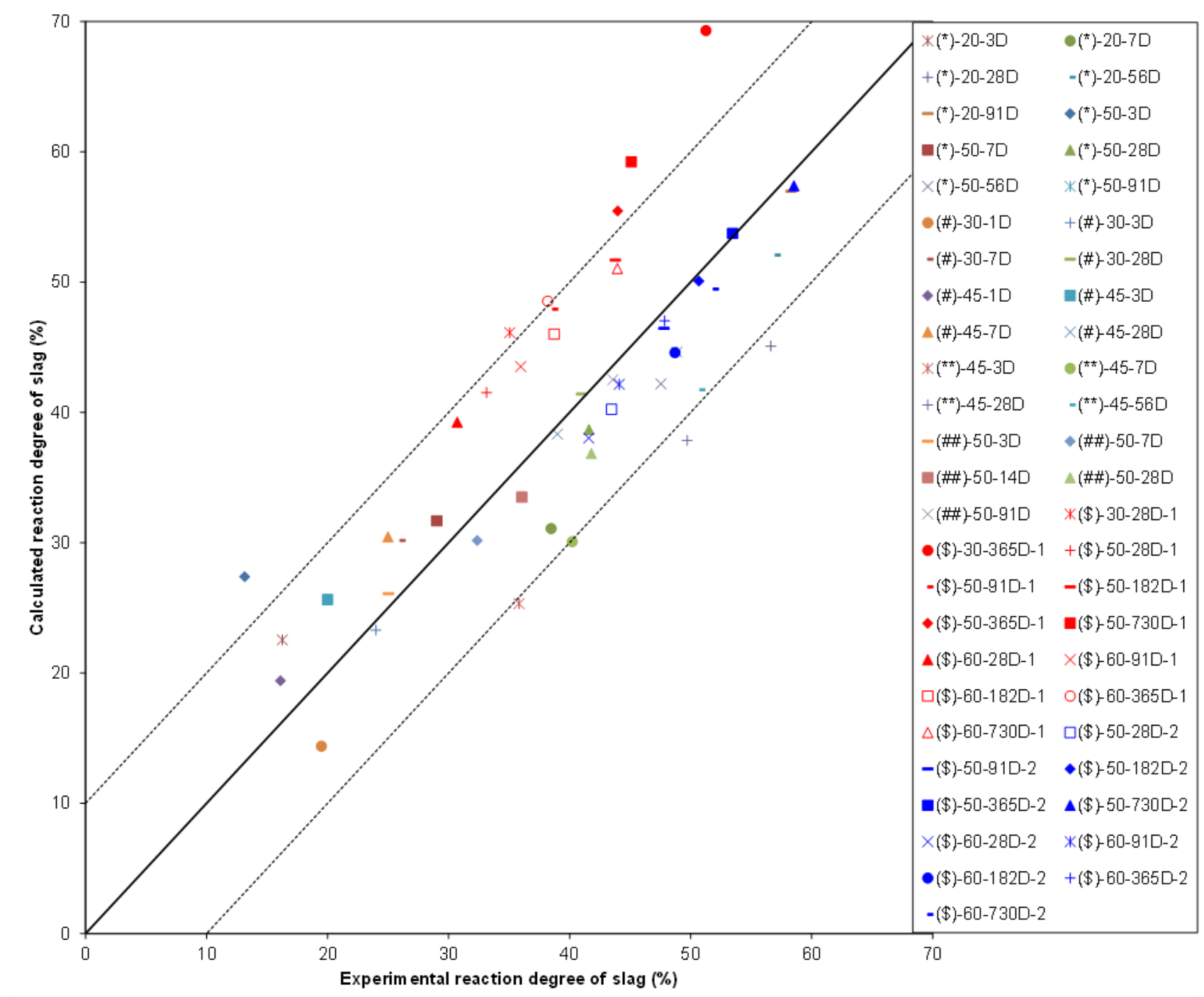

308 Fig. 5. Comparison of calculated reaction degree of slag using Eq. (12) with published (\$[26], $309 \# \#[27], * *[28], *[29]$, and \#[30]) experimental data. The dotted lines show $\pm 10 \%$ deviation from y $310=\mathrm{x}$ line. Notation: ( )-xx-yD: Reference-slag replacement ratio-curing period in days. Two types of 311 slag in ref. (Lumley et al., 1996) are used.

\subsubsection{Simulation results and experimental data verification}


315 The calculated composition of hydrates and the remaining un-reacted slag and clinker of the slag 316 cement system, which consists of $60 \%$ OPC and $40 \%$ slag, as a function of hydration time are 317 shown in Fig. 6(A) for the input parameters given in Table 3 and the composition of slag tabulated 318 in Table 4. The predicted monocarboaluminate, which is formed through the dissolution of calcite, 319 is completely changed to hemicarboaluminate after approximately 7 days of hydration, thus 320 destabilising ettringite. The hydrated slag cement, with a degree of slag reaction of more than $70 \%$, 321 has C-A-S-H solid solution, monosulfoaluminate, hydrotalcite, and monocarboaluminate, in 322 addition to decreasing trend of portlandite and ettringite as the main hydration products. The 323 calculated $\mathrm{Ca} / \mathrm{Si}$ and $\mathrm{Al} / \mathrm{Si}$ ratios of $\mathrm{C}-\mathrm{A}-\mathrm{S}-\mathrm{H}$ as a function of hydration time are shown in Fig. 6(B).

324 Table 4 Mineral composition of slag and chemical composition of glass in the slag

\begin{tabular}{llll}
\hline \multicolumn{2}{l}{ Mineral composition (wt. \%) } & \multicolumn{2}{c}{ Glass composition (wt. \%) } \\
-Anhydrite & 3.1 & $-\mathrm{SiO}_{2}$ & 30.80 \\
-Glass & 96.9 & $-\mathrm{Al}_{2} \mathrm{O}_{3}$ & 13.80 \\
Total & 100.0 & $-\mathrm{Fe}_{2} \mathrm{O}_{3}$ & 0.29 \\
& & $-\mathrm{CaO}$ & 44.00 \\
& & $-\mathrm{MgO}$ & 6.00 \\
& & $-\mathrm{SO}_{3}$ & 3.45 \\
& $-\mathrm{Na}_{2} \mathrm{O}$ & 0.23 \\
& $-\mathrm{K}_{2} \mathrm{O}$ & 0.28 \\
& & $\mathrm{Total}$ & 98.85 \\
\hline
\end{tabular}




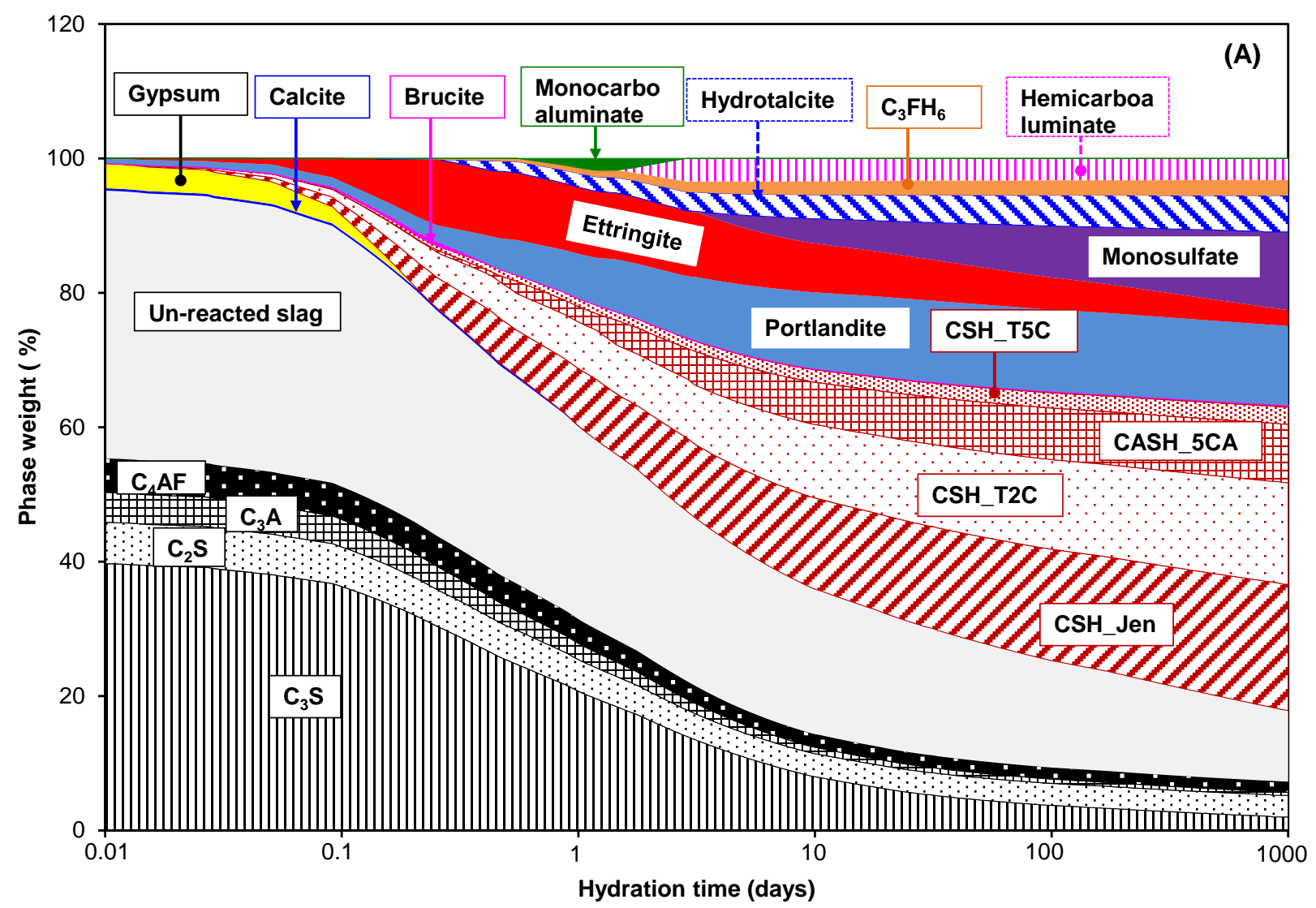

Hydration time (days)

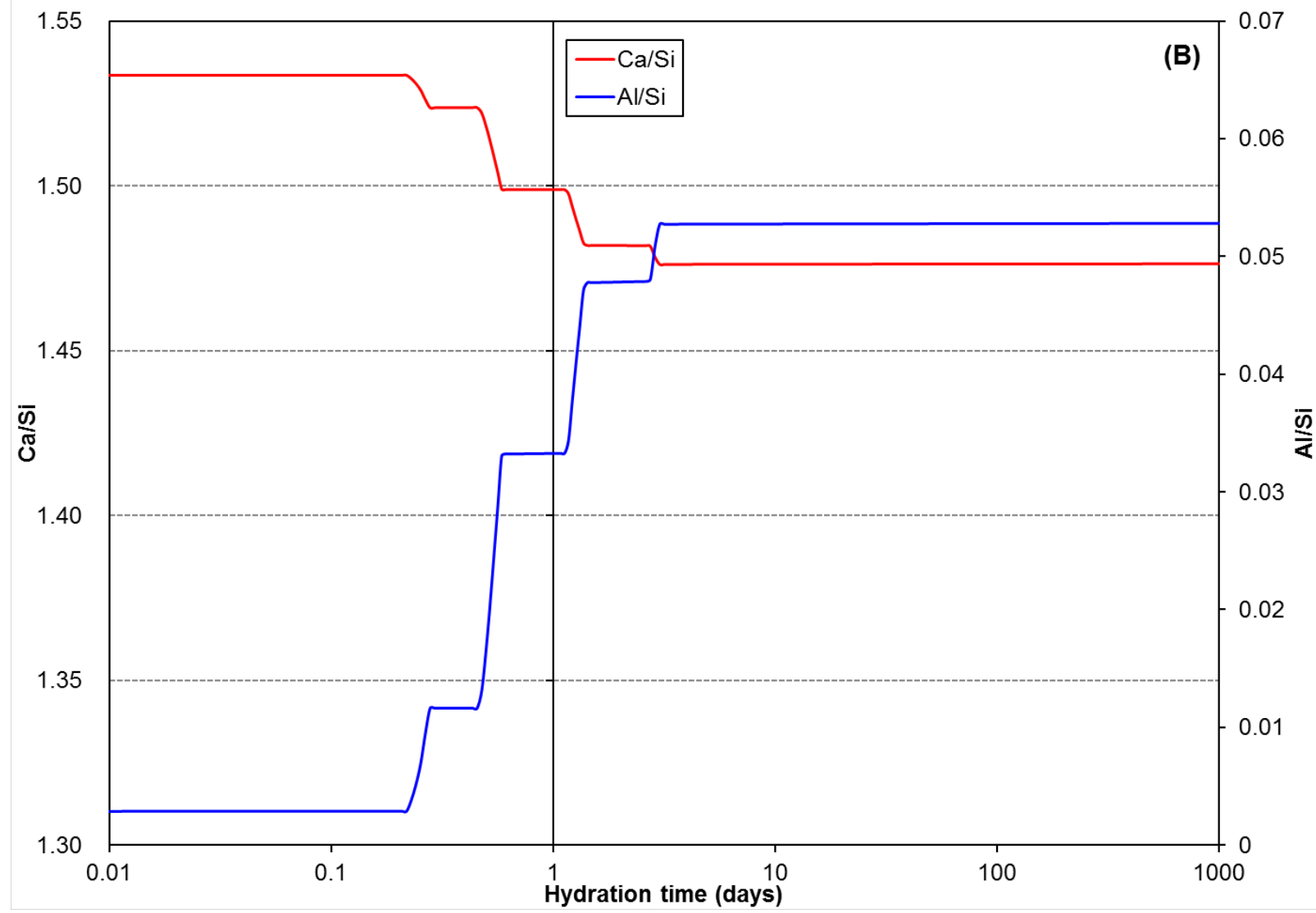

328 Fig. 6. Simulated phase (A), $\mathrm{Ca} / \mathrm{Si}$ and $\mathrm{Al} / \mathrm{Si}$ ratios of $\mathrm{C}-\mathrm{A}-\mathrm{S}-\mathrm{H}$ (B) changes as a function of

329 hydration time for cement blended with slag (OPC: slag $=60: 40)$ 

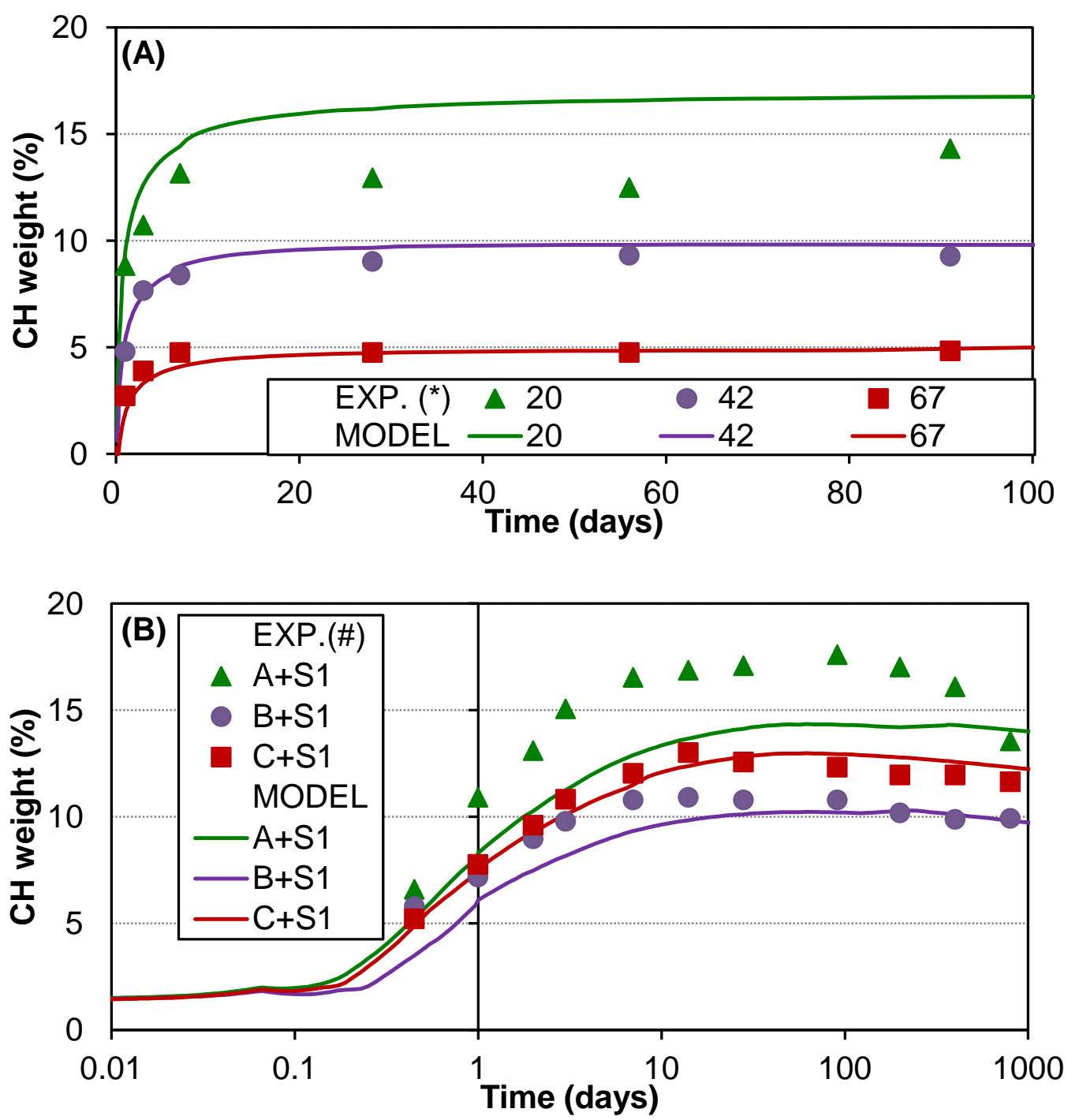

Fig. 7. Comparison of simulated portlandite changes with experimental data $(*[32]$ and \#[33]) for (A) various slag replacement ratios and (B) a constant replacement of $40 \%$ slag with various types of Portland cement as a function of hydration time for cement blended with slag

Fig. 7 compares the portlandite weight percentage predicted by the model and that determined by experiments [32-33] as a function of hydration time. The influence of the slag replacement ratio on the consumption of portlandite is shown in Fig. 7(A) while the effect of the chemical composition of Portland cement on the portlandite formation of the slag cement system is given in Fig. 7(B). The same composition of cement and slag and the mixing conditions as those given in ref. [32-33] were 342 adopted in the simulation. In addition to a consistent trend between the predicted and measured values, the calculated portlandite content agrees very well with experimental results except for a 
mixture containing 20\% slag (20 in Fig. 7 (A)) and white cement blended with slag (A+S1 in Fig.

345 7(B)). The portlandite has not completely consumed by slag hydration, even for a high replacement 346 of slag and a long hydration time.

348 The main hydrates of the slag-blended cement (OPC:slag = 60:40) and slag and limestone-blended 349 cement (OPC:slag:LS $=57.7: 38.5: 3.8)$ were predicted using the same details as those used in the 350 experiment [34] as input, and the results are compared to XRD/Rietveld data in Fig. 8 and Fig. 9 351 respectively. The calculated phase changes show the same tendency as the measured data. The 352 predicted portlandite, ettringite, monosulfoaluminate, monocarboaluminate, calcite, and un-reacted 353 slag weight percentage show good agreement with experimental values, but the model slightly 354 underestimates the amount of C-S-H/C-A-S-H in the hydrating slag-blended cement. Further, both 355 the XRD results and the model predictions agree on the absence of monosulfoaluminate in the 356 hydrated slag and limestone-blended cement, whereas the experimental results show the presence of 357 hemicarboaluminate in the hydrates but the model did not predict it (Fig. 9). The element 358 concentration predicted in the pore solution of the hydrating slag-blended cement is compared with 359 experimentally determined values [35-36] in Fig. 10. The predicted dominant elements in the pore 360 solution are consistent with experimental observations, and also the model predicts well the 361 decrease of alkali concentration in the pore solution with increasing slag proportions as observed in 362 the experiment. 

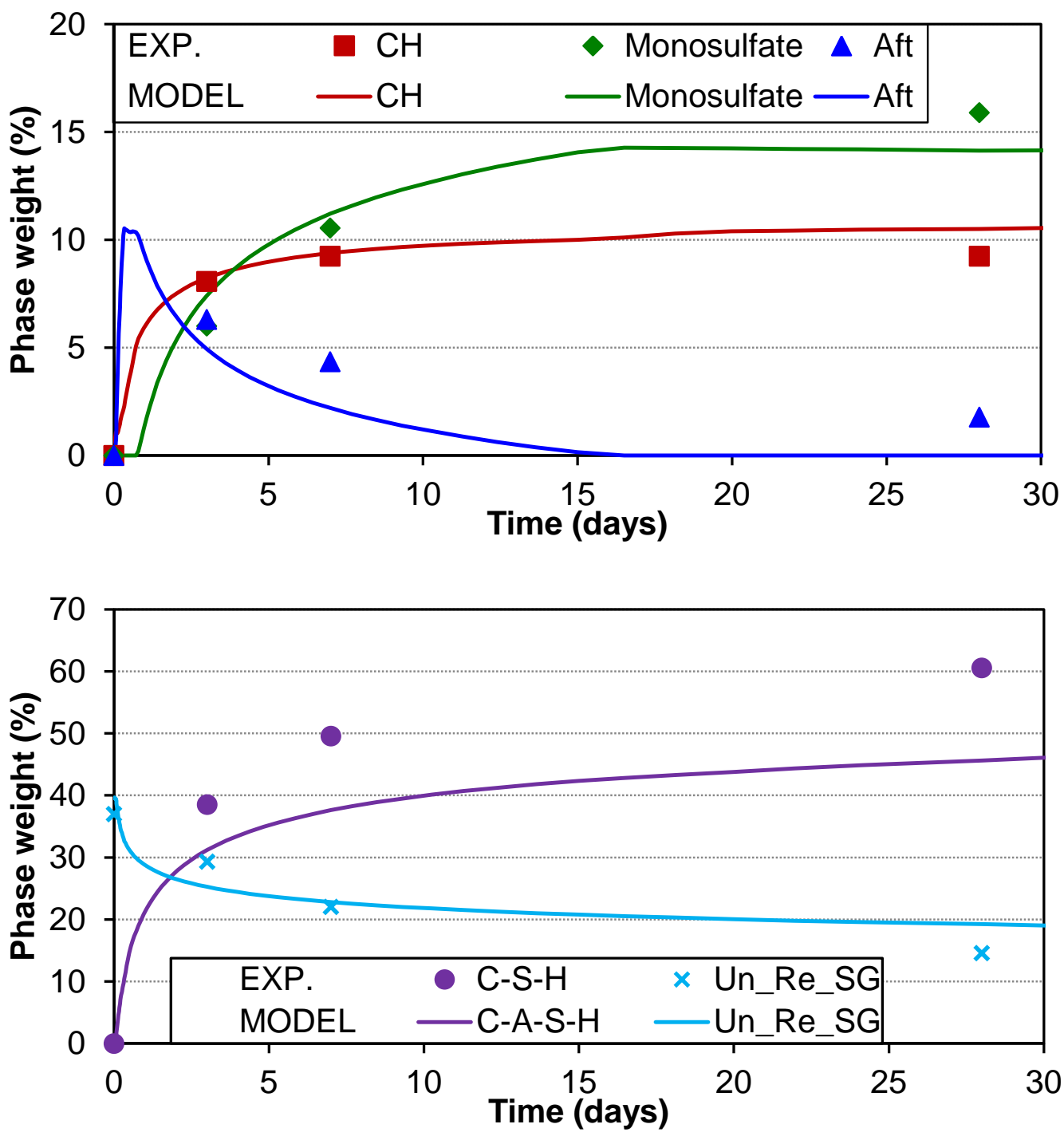

366 Fig. 8. Comparison of simulated portlandite $(\mathrm{CH})$, monosulfate, ettringite (Aft), C-S-H/C-A-S-H 367 and un-reacted slag (Un_Re_SG) changes with experimental data [34] as a function of hydration 368 time for cement blended with slag (OPC: slag $=60: 40)$

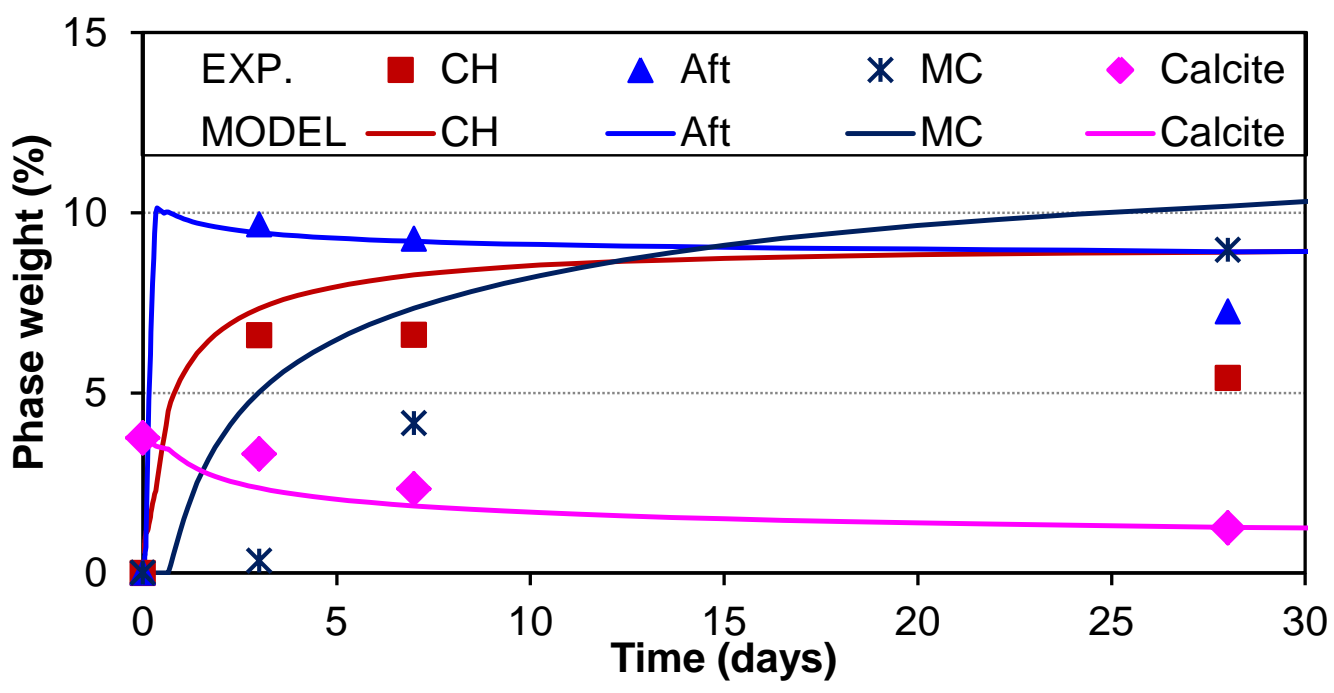




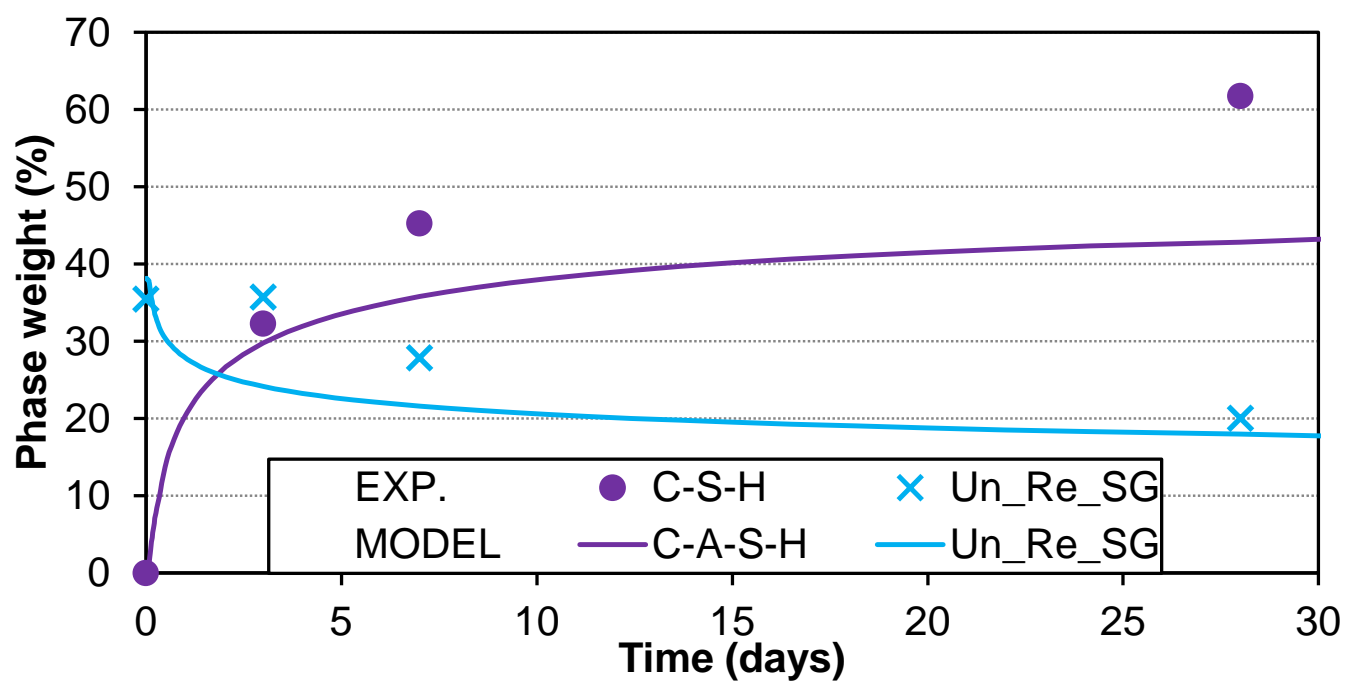

371 Fig. 9. Comparison of simulated portlandite (CH), ettringite (Aft), monocarboaluminate (MC),

372 calcite, C-S-H/C-A-S-H and un-reacted slag (Un_Re_SG) changes with experimental data [34] as a 373 function of hydration time for cement blended with slag and limestone (OPC: slag: LS = 57.7: 38.5:

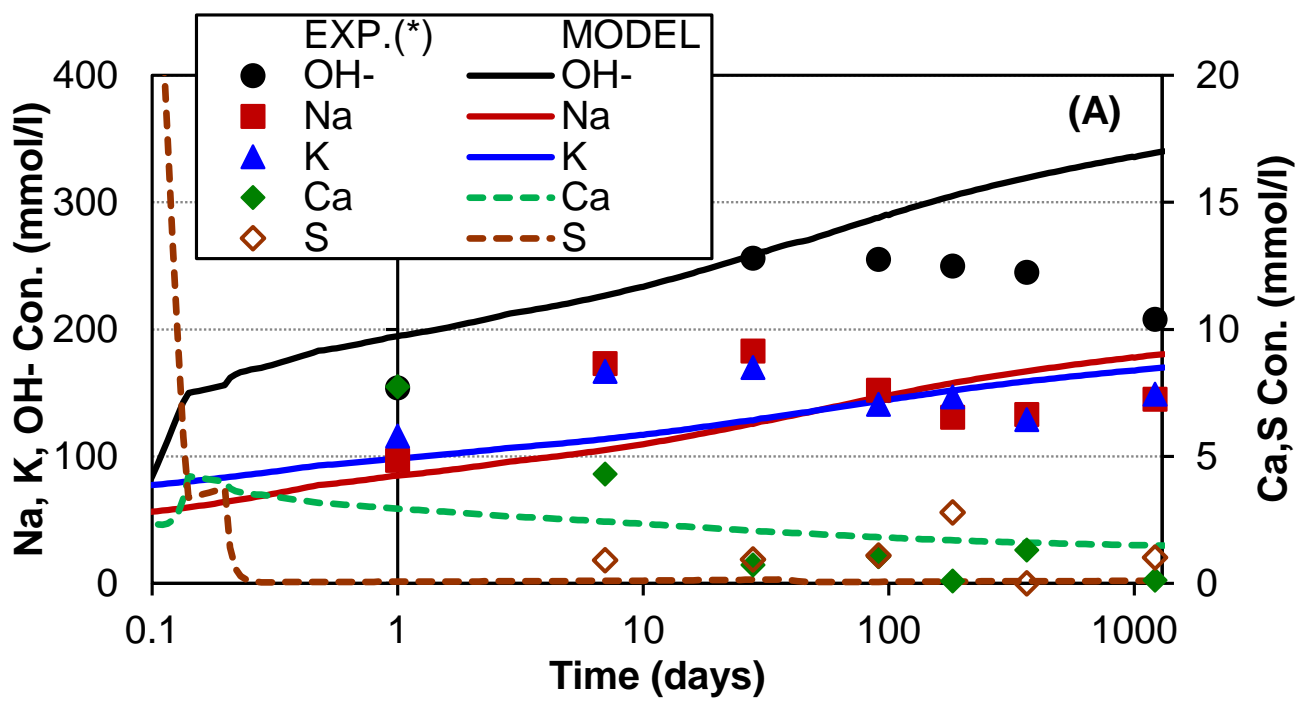




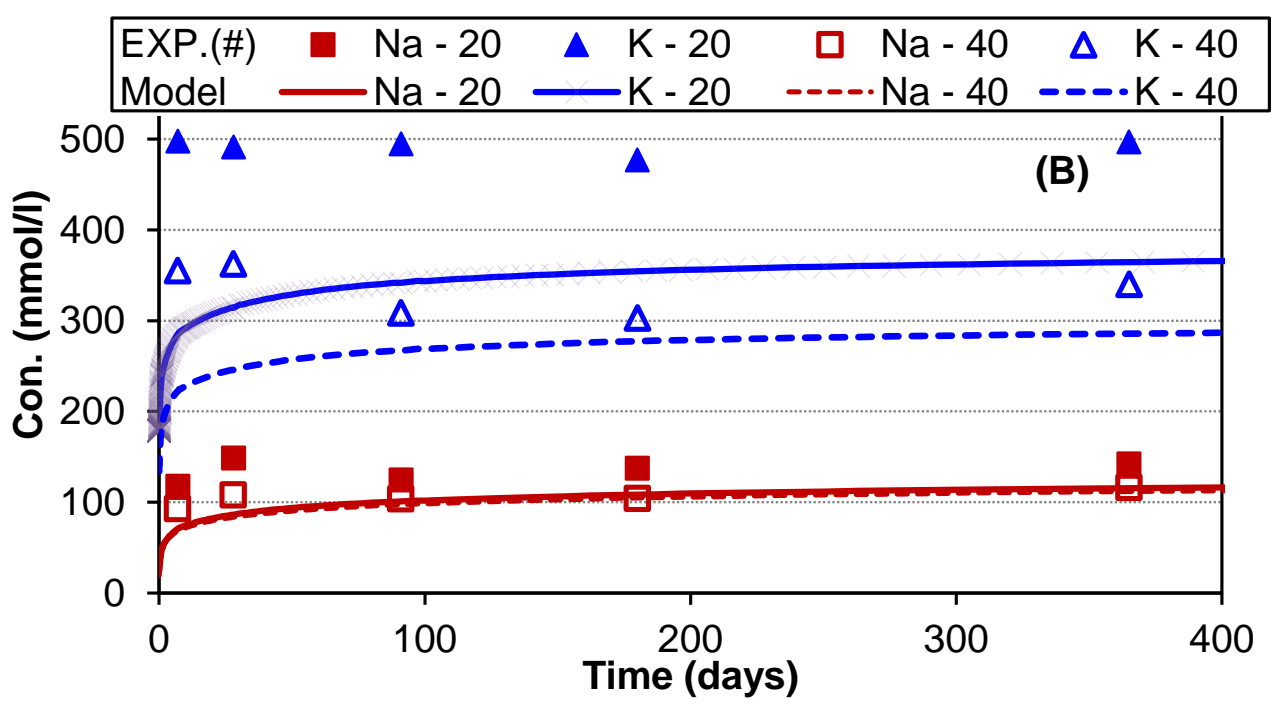

378 Fig. 10. Comparison of simulated pore solution/alkali concentration changes with experimental data $379(*[35] ; \#[36])$ for $(\mathrm{A})$ cement blended slag (OPC: slag $=50: 50)$ and $(\mathrm{B})$ cement containing $20 \%$ and $380 \quad 40 \%$ of slag

\section{DISCUSSION}

As demonstrated by the agreement between the experimental data and simulations results in slag cement systems, the approach used here can be applied to predict the compositions of the hydrate assemblage and pore solution. It should be noted that most of the slags used as supplementary cementitious materials have rather similar chemical compositions and high amorphous content. Different experimental results [32-36], which did not consider in the deriving equation (Eq. (12)) for slag reaction, have used to verify the hydration in slag-blended cement systems (Fig. 7-Fig. 10). This suggests a wider applicable range for the derived equation. However, the suitability of using this derived equation for a high replacement of cement by slag needs to be assessed because the equation was obtained for replacement levels of up to $60 \%$ slag.

The calculated results show the same kind of hydration products, such as C-A-S-H, portlandite, ettringite, hydrotalcite, and AFm phases, as observed in the experiments for hydrating Portland cement and cement blended with slag. Furthermore, the predicted quantities of the phases agree 
well with the experimental values. The predicted $\mathrm{Ca} / \mathrm{Si}$ and $\mathrm{Al} / \mathrm{Si}$ ratios of $\mathrm{C}-\mathrm{A}-\mathrm{S}-\mathrm{H}$ in hydrated

398 OPC and slag-blended cements are compared with experimental data in Table 5. The distribution 399 among four end-members of the initially selected six end-members determines the $\mathrm{Ca} / \mathrm{Si}$ ratio of 400 C-A-S-H, and the fraction of the CASH_5CA member controls the Al/Si ratio because the presence 401 of the CASH_INFCA member is negligible. The consideration of low Ca/Si ratio of C-S-H as 402 end-members of C-A-S-H solid solution in OPC decreases its $\mathrm{Ca} / \mathrm{Si}$ ratio, whereas the low amount 403 of CASH_5CA decreases the Al/Si ratio in slag-blended cement.

Table 5 Comparison between predicted and experimental $\mathrm{Ca} / \mathrm{Si}$ and $\mathrm{Al} / \mathrm{Si}$ ratios of $\mathrm{C}-\mathrm{A}-\mathrm{S}-\mathrm{H}$ in hydrated OPC and blended cements. Experimental data from * [2, 12, and 33] and ${ }^{\#}$ [33]

\begin{tabular}{|c|c|c|c|c|c|}
\hline & \multicolumn{2}{|l|}{$\mathrm{Ca} / \mathrm{Si}$} & \multicolumn{2}{|l|}{$\mathrm{Al} / \mathrm{Si}$} & \multirow{2}{*}{$\begin{array}{l}\text { Time } \\
\text { (days) }\end{array}$} \\
\hline & Experimental & Predicted & Experimental & Predicted & \\
\hline $\mathrm{OPC}^{*}$ & $\approx 1.80$ & 1.48 & $\approx 0.05$ & 0.05 & 400 \\
\hline OPC: slag $=60: 40^{\#}$ & $\approx 1.55$ & 1.47 & $\approx 0.15$ & 0.06 & 400 \\
\hline
\end{tabular}

A series of simulations were performed to evaluate the significance of the C-A-S-H solid solution in terms of precisely predicting the hydration products. The simulated portlandite weight percentage in the OPC and slag-blended cement was compared with experimental measurements in Fig. $\mathbf{1 1}$ as an example. The simulation results for the case with six end-members of the C-A-S-H solid solution are shown in Fig. 11(A), along with the results of four end-members (without CASH_INFCA and CSH_TobH). The predicted results using four end-members of the solid solution match exactly with 414 those using six end-members because the fractions of CASH_INFCA and CSH_TobH are insignificant (Fig. 1(A) and Fig. 6(A)). Both the predicted and the measured results are very close to the $y=x$ line for the OPC and blended cement, indicating the importance of six or four end-members of the C-A-S-H solid solution.

In contrast, another simulation was performed in which phase-equilibrium model with only 
421 modelled results are consistent with the experimental values for OPC, as observed in the case of the 422 solid solution, which suggests that either a C-A-S-H solid solution or a CSH_Jen phase-equilibrium 423 model can be used. However, poor agreement was found for the OPC containing slag, where 424 incorporation of the CSH_Jen phase-equilibrium model underestimated the portlandite content in 425 the blended cement. Therefore, it is important to consider the C-A-S-H solid solution model in 426 order to predict precisely the hydration products in the blended cement. Despite some discrepancies 427 in the $\mathrm{Ca} / \mathrm{Si}$ or $\mathrm{Al} / \mathrm{Si}$ ratio of $\mathrm{C}-\mathrm{A}-\mathrm{S}-\mathrm{H}$, the $\mathrm{C}-\mathrm{A}-\mathrm{S}-\mathrm{H}$ solid solution model is more suitable for 428 predicting the hydration products of both OPC and slag-blended cement. Future research on the 429 thermodynamic models and laboratory experiments on C-A-S-H and the inclusion of other phases 430 as end-members would enable us to predict $\mathrm{Ca} / \mathrm{Si}$ and $\mathrm{Al} / \mathrm{Si}$ ratios in the blended cements more 431 accurately. 


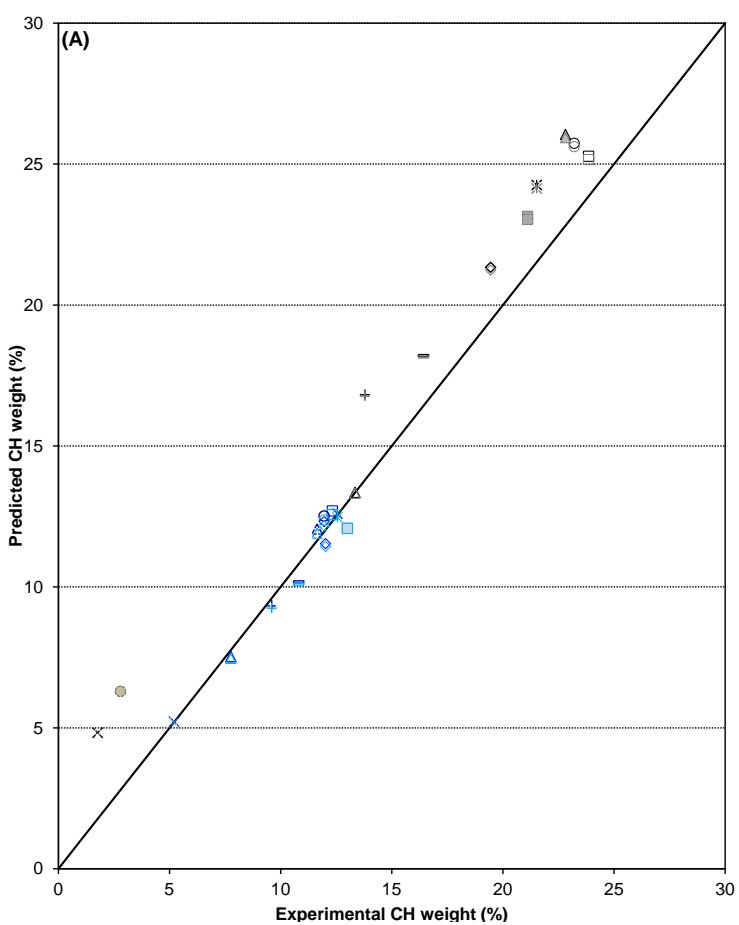

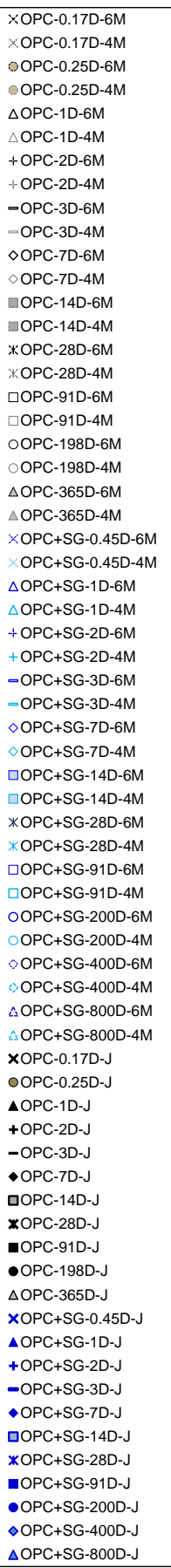

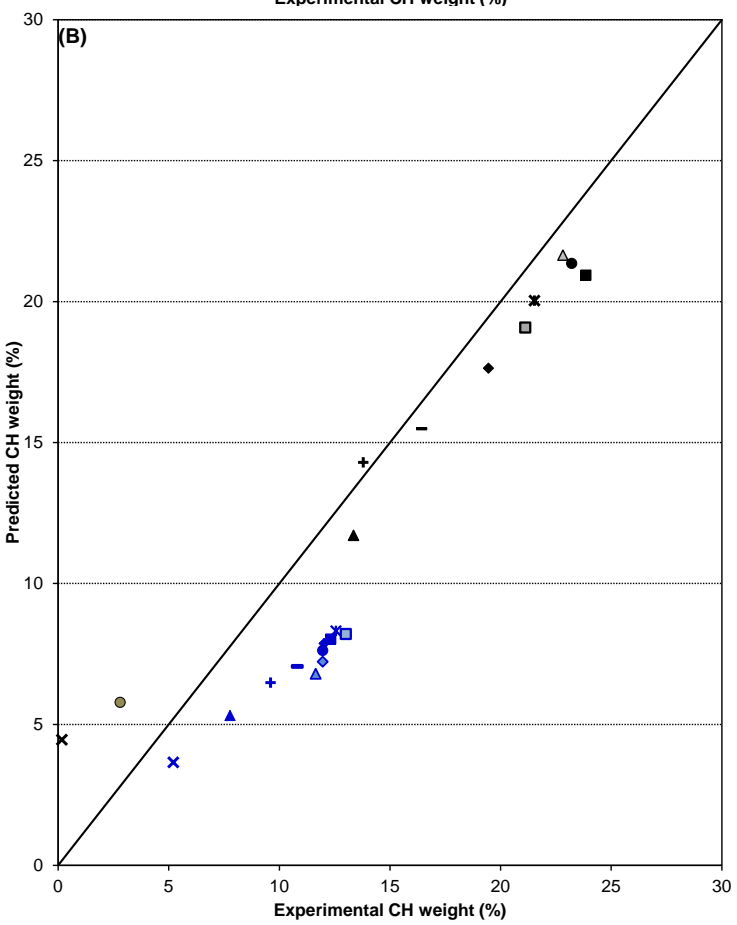

435 Fig. 11. Comparison of predicted portlandite weight percentage with experimental data [9 and 33] considering (A) C-A-S-H solid solution model and (B) without C-A-S-H solid solution model, but considered only the CSH_Jen phase for C-S-H. Notation: AA-xD-6M/4M/J: Binder-curing period in days-six end-members (CSH_Jen, CSH_T2C, CASH_5CA, CSH_T5C, CASH_INFCA and CSH_TobH) or four end-members (CSH_Jen, CSH_T2C, CASH_5CA, and CSH_T5C) solid solution for C-A-S-H or considered only the CSH_Jen phase. 


\section{CONCLUSIONS}

444 The composition of the hydrate assemblage and pore solution chemistry of OPC and slag-blended cement as a function of hydration time were predicted using the PHREEQC integrated with empirical expressions for the dissolution of clinker minerals and reactions of slag. The main hydration products, such as C-A-S-H, portlandite, ettringite, hydrotalcite, and AFm phases, and major elements in the pore solution, such as $\mathrm{Na}, \mathrm{K}, \mathrm{OH}, \mathrm{Ca}, \mathrm{S}, \mathrm{Al}$, and $\mathrm{Si}$, were predicted for the input of the chemical compositions of OPC and slag and mixing conditions. The considered solid solution model for $\mathrm{C}-\mathrm{A}-\mathrm{S}-\mathrm{H}$ explains the varying $\mathrm{Ca} / \mathrm{Si}$ and $\mathrm{Al} / \mathrm{Si}$ ratios due to hydration and the addition of slag. The predicted results were verified with experimental data reported in the literature.

The types of phases in the model predictions for hydrating Portland cement, cement blended with slag, and blended cement containing limestone were consistent with the experimental observations,

454 and both the calculated and measured quantities showed good agreement. The predicted elements and the concentrations in the pore solution agreed well with the experimental results, but a proper model for the uptake of alkalis by C-A-S-H is necessary for better predictions in slag-blended cements. Comparing the simulated results considering the C-A-S-H solid solution model or not with experimental data for portlandite as an example emphasised the significance of the solid solution model in predicting the hydration products in slag-blended cement.

\section{REFERENCES}

1. M. S. Imbabi, C. Carrigan, S. McKenna, Trends and development in green cement and concrete technology, International Journal of Sustainable Built Environment 1 (2012) 194-216.

2. B. Lothenbach, K. Scrivener, R.D. Hooton, Supplementary cementitious materials, Cem. Concr. Res. 41 (2011) 1244-1256.

3. S. Miyahara et al. Durability and applications of environmental-friendly concrete with slag 
and calcium activator, $5^{\text {th }}$ International Conference on Construction Materials (ConMat'15), (2015).

4. D. Rothstein, J. J. Thomas, B. J. Christensen, H. M. Jennings, Solubility of Ca-, S-, Al-, and Si-bearing solid phases in Portland cement pore solutions as a function of hydration time, Cem. Concr. Res. 32 (2002) 1663-1671.

5. A. Gruskovnjak et al., Hydration mechanism of super sulphated slag cement, Cem. Concr. Res. 38 (2008) 983-992.

6. R. Loser, B. Lothenbach, A. Leemann, M. Tuchschmid, Chloride resistance of concrete and its binding capacity - comparison between experimental results and thermodynamic modeling, Cement \& Concrete Composites 32 (2010) 34-42.

7. B. Lothenbach, F. Winnefeld, Thermodynamic modelling of the hydration of Portland cement, Cem. Concr. Res. 36 (2006) 209-226.

8. B. Lothenbach, E. Wieland, A thermodynamic approach to the hydration of sulphate-resisting Portland cement, Waste Management 26 (2006) 706-719.

9. B. Lothenbach, G. Le Saout, E. Gallucci, K. Scrivener, Influence of limestone on the hydration of Portland cements, Cem. Concr. Res. 38 (2008) 848-860.

10. B. Lothenbach et al., Thermodynamic modelling of the effect of temperature on the hydration and porosity of Portland cement, Cem. Concr. Res. 38 (2008) 1-18.

11. B. Lothenbach et al., Sulfate ingress in Portland cement, Cem. Concr. Res. 40 (2010) 12111225.

12. K. De Weerdt et al., Hydration mechanisms of ternary Portland cements containing limestone powder and fly ash, Cem. Concr. Res. 40 (2011) 279-291.

13. Y. Elakneswaran and T. Ishida, Development and verification of an integrated physicochemical and geochemical modelling framework for performance assessment of cement-based materials, Journal of Advanced Concrete Technology, 12, (2014), 111-126.

14. B. Kolani et al., Hydration of slag-blended cements, Cement \& Concrete Composites 34 (2012) 
1009-1018.

15. R. J. Myers, S. A. Bernal, J. L. Provis, A thermodynamic model for C-(N-)A-S-H gel: CNASH_ss. Derivation and validation, Cem. Concr. Res. 66 (2014) 27-47.

16. I. G. Richardson and G. W. Groves, Microstructure and microanalysis of hardened cement pastes involving ground granulated blast-furnace slag, J Mater Sci., 27, (1992), 6204-6212.

17. C. A. J. Appelo, D. Postma, Geochemistry, groundwater and pollution: CRC Press Taylor \& Francis Group, 2009.

501 18. D. L. Parkhust, C. A. J. Appelo, A computer program for speciation, batch-reaction, one-dimensional transport and inverse geochemical calculations, USGS report 1999.

19. K.S. Pitzer, Ion interaction approach: theory and data correlation, in: K.S. Pitzer (Ed.), Activity

21. L. J. Parrot, D. C. Killoh, Prediction of cement hydration, British Ceramic Proceedings 35 (1984) 41-53.

22. S. R. Charlton, D. L. Parkhurst, Modules based on the geochemical model PHREEQC for use in scripting and programming languages, Computers \& Geosciences 37 (2011) 1653-1663.

23. W. Chen and H. J. H. Brouwers, Alkali binding in hydrated Portland cement paste, Cement and Concrete Research, 40, (2010), 716-722.

24. T. Matschei, B. Lothenbach, F.P. Glasser, The AFm phase in Portland cement, Cem. Concr. Res. 37 (2007) 118-130.

25. L.A Larbi, et al, The chemistry of pore fluid of silica fume-blended cement systems, Cement and Concrete Research, 20, (1990), 506-516.

26. J. S. Lumley, R. S. Gollop, G. K. Moir, H. F. W. Taylor, Degrees of reaction of the slag in some blends with Portland cements, Cem. Concr. Res. 26 (1996)139-51.

27. T. Sagawa, T. Nawa, Hydration of blast furnace slag cement and effect of water to cement ration 
on hydration of blast furnace slag cement, Cement Science and Concrete Technology 60 (2006) 82-87. (In Japanese)

28. T. Sagawa, T. Ishida, Y. Luan, T. Nawa, Hydrate composition analysis and micro structure characteristics of Portland cement-blast furnace slag system, Journal of JSCE E 66 (2010) 311324. (In Japanese)

29. E. Sakai, H. Imoto, M. Daimon, Hydration and strength development of blast furnace slag cement, Proceedings of JCI 26 (2004) 135-140. (In Japanese)

30. N. Takamatsu, I. Maruyama, Study on volume deformation and hydration degree of blast furnace slag replaced matrix, Proceedings of JCI 31 (2009) 187-192. (In Japanese)

31. S.J. Barnett, M.N. Soutsos, S.G. Millard, J.H. Bungey, Strength development of mortars containing ground granulated blast-furnace slag: Effect of curing temperature and determination of apparent activation energies, Cem. Concr. Res. 36 (2006)434-440.

32. T. Iyoda, Y. Dan, The effect of temperature on hydration rate of slag in blended cement, Proceeding of JSCE 333 committee symposium (2007) II59-62. (In Japanese)

33. V. Kocaba, Development and evaluation of methods to follow microstructural development of

36. E. Schafer, "Einfluss der Reaktionen verschiedener Zementbestandteile auf den alkalihaushalt der Porenlösung des Zementsteins”, PhD thesis, Clausthal University of Technology, 